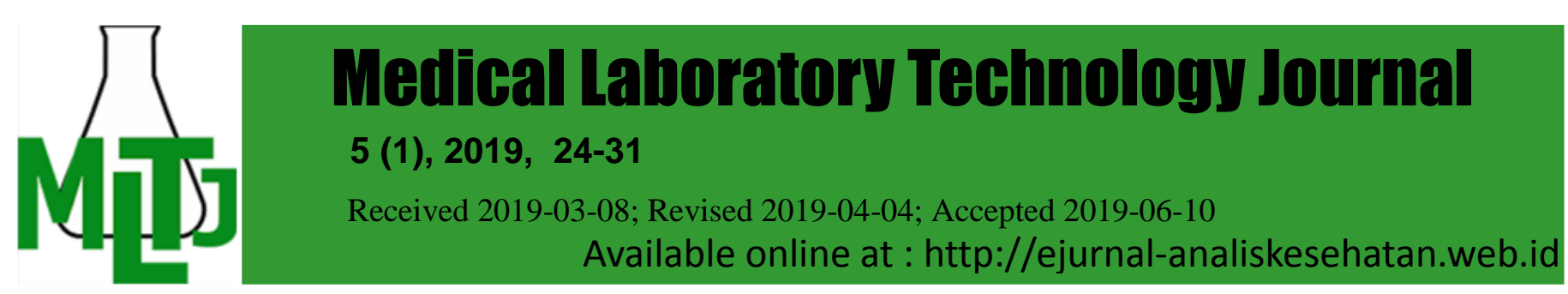

\title{
Microfilaria Detection on Giemsa Blood Smears using Real-Time PCR
}

\author{
*Paisal, Erli Haryati, Dwi Candra Arianti, M. Rasyid Ridha, Annida \\ Balai Litbang Kesehatan Tanah Bumbu, Jl. Lokalitbang Kel. Gunung Tinggi, \\ Kecamatan Batulicin, Kabupaten Tanah Bumbu, Kalimantan Selatan, 72271, \\ Indonesia. *Email: paisal.zain@gmail.com \\ DOI: $10.31964 / \mathrm{mltj} . v \%$ vi\%i.210
}

\begin{abstract}
Filariasis is an infectious disease caused by filarial worms, which found in many tropical and subtropical regions. In 2017, 12,677 cases of chronic filariasis were found in Indonesia, which 132 cases of them were from Central Kalimantan province. Data of Kapuas District Health Office shows 17 cases filariasis in 2015. Frequently, filariasis patients did not show any diseases symptoms, especially when the level of microfilariae in the blood is deficient. On the other hand, microscopic assay with Giemsa blood smears is still the gold standard to define filariasis. Thus, a false negative result may occur due to a low level of microfilariae in the blood. In this study, we develop a real-time PCR method, targeting the Hhal gene of filaria, to detect filarial worm from stored Giemsa blood taken from filariasis patients, in both dry and wet scraping methods. Our result shows that real-time PCR can detect Brugia malayi in all scraping samples, with Ct value from wet scraping sample tends to be higher than dry scraping. In conclusion, the real-time PCR method can be further used to define filariasis, especially in the condition when Giemsa smear blood cannot determine patient filariasis status.
\end{abstract}

Keyword : filariasis; Brugia malayi; real-time PCR; giemsa blood smear

\section{INTRODUCTION}

According to $\mathrm{WHO}$, around 120 million people, especially in tropical and subtropical countries, are infected with filaria, with 40 million cases are having significant clinical symptoms (WHO, 2015). In Indonesia, in 2017, there are 12,677 cases of chronic filariasis, with most cases were found in Papua Province $(3,047$ cases), East Nusa Tenggara (2,864 cases), and West Papua (1,244 cases). Meanwhile, Central Kalimantan Province reporting 132 cases, ranked 17th out of 34th provinces all over Indonesia (Ministry of Health, 2018). In Kapuas District itself, in 2014 and 2015, there were 14 and 15 reported filariasis cases, respectively (Kapuas District Health Office, 2015).

Filariasis is a disease caused by infection of filarial worms which transmitted to human through mosquito vectors, such as mansonia, anopheles, and aedes. Three dominant filarial species that infect human are Brugia malayi, Brugia timori, and Wuchereria bancrofti (Gleave et al., 2016). Filarial worms can cause chronic lymphedema which manifests as swelling in the legs, scrotum, hands, or other body parts. At present, these symptoms are relatively rare. Conversely, some people with filariasis do not show signs or asymptomatic (chronic filariae) due to the low amount of microfilariae in the blood. Asymptomatic filariae are now commonly occurred with the implementation of a mass prevention drug administration program (Pemberian Obat Pencegahan Massal, POPM) by the Indonesia Ministry of Health (Wongkamchai et al., 2014). 
To define filarial status, Giemsa microscopic examination of blood smears is still the gold standard. This examination detects the presence of microfilariae in the blood, which its sensitivity depended on the number of microfilaria in the blood. Thus, false negative may occur when the number of microfilariae is deficient. In the case of low microfilaremia, PCR examination become another optional method to detect filaria, for its reliability and higher sensitivity (Albers et al., 2014).

PCR examination to detect filaria is usually performed from blood samples taken from veins or fingers which stored in vacutainer, container, or filter paper (Smit et al., 2014). In the situation where further laboratory confirmation test for filariasis cases is needed, and only blood smear samples are available, PCR examination can still be performed (Ferlianti et al., 2012).

In this study, we conducted a PCR examination using stored blood smears taken from a person with $B$. malayi. The study aimed to confirm the results of microscopic examination with real-time PCR and to compare the methods of dry and wet scrapings in extracting DNA from blood smears. In our knowledge, no studies were examining Giemsa blood smear of $B$. malayi using real-time PCR. Other studies carried out real-time PCR on blood smears of $W$. bancrofti (Ferlianti et al., 2012), Plasmodium sp. (Wihokhoen et al., 2016), and Leishmania spp (Khademvatan et al., 2011).

\section{MATERIALS AND METHODS Stored blood smear sample}

Stored blood smear sample previously collected from Dadahup Village, Dadahup Subdistrict, Kapuas District, Central Kalimantan in November 2015 under the ethical protocol number LB.02.01/5.2/KE.056/2015 by Ethics Commission National Institute of Health Research and Development (NIHRD) Indonesia. Giemsa blood smear examination conducted at the P2B2 Tanah Bumbu Research and Development Center, South Kalimantan, in July 2018, and blood slide was stored in $\mathrm{RT}$ inside slide box until further used for PCR test.

\section{Characteristics of patient}

Blood sample came from a 57-year-old male working as a rubber tapper for the last eight years, with work time between 6 am and $2 \mathrm{pm}$. He lived in Dadahup Village since childhood and never lived outside the village. The symptoms he felt were unclear with no sign of chronic lymphedema. He only complained of body aches and repetitive chills with seldom visit the local health officer for the complaint.

\section{Microscopic examination}

The blood smear is made by fingertips piercing with lancet which taken within 2 hours interval for 24 hours, followed by placed off 2-3 drops of blood on the glass deck. The blood is flattened with the other end of the slide until it is quite thin and oval shaped. Further, slides are air-dried and colored with Giemsa. Microfilaria detection was carried out under Eclipse E-100 Microscope (Nikon, Japan) in 100x magnification.

\section{Real-time PCR}

\section{Primer and Probe}

Hhal repetitive gene was used as a target gene to detect Brugia species which designed as standard Brugia DNA sequence (GenBank Access No.M12691 and AF499109 to AF499129). Around 120 bp, DNA amplicon will recognize (Rao et 
al., 2006).

Table 1. Primer and Probe Sequence

\begin{tabular}{ll}
\hline NAME & SEQUENCE \\
\hline MGB-Hhal-For & 5 '-GCAATATACGACCAGCAC-3' \\
MGB-Hhal-Rev & 5'-ACATTAGACAAGGAAATTG GTT-3 ' \\
MGB-Hhal-probe & 5'-TTTTTAGTAGTTTT GGC-3 ' \\
\hline
\end{tabular}

\section{DNA Extraction}

The blood smear used as a sample is a 2.5 years old stored slide which its total DNA will be extracted using blood DNA extraction kit (Vivantis, Malaysia). Two slides of a blood smear from one patient treated differently. The first slide was scraped in dry conditions using a scalpel and the results of the scrapings were placed in a $1.5 \mathrm{ml}$ tube. The second slide previously moistened with three drops of BB Buffer stirred using a pipette tip, then the sample was put into a container. Approximately $200 \mu$ l of venous blood also extracted for its total DNA.

Further extraction steps are done following the kit instructions. Samples was added $200 \mu \mathrm{l} \mathrm{BB}$ buffer, $20 \mu \mathrm{l}$ proteinase $\mathrm{K}$, and incubated $65^{\circ} \mathrm{C}$ for 10 minutes. The mixtures were combined with $200 \mu \mathrm{l}$ of absolute ethanol and transferred to the columns, then centrifuged at a speed of $5000 \mathrm{~g}$ for 1 minute. The column was washed with $500 \mu \mathrm{l}$ of wash buffer 1 and 2, and centrifuged at a rate of $5000 \mathrm{~g}$ for 1 minute and 3 minutes, respectively. Then $100 \mathrm{~mL}$ of elution buffer was added to the column and incubated for 2 minutes at room temperature. The final step was to centrifuge the column at a speed of $5000 \mathrm{~g}$ for 1 minute, to release the DNA from the column. Extracted DNA was stored at $4{ }^{\circ} \mathrm{C}$ until further used.

\section{PCR}

Real-time PCR is performed using Quant Studio 5 (Applied Biosystem, USA), with a method that was previously published (Rao et al., 2006). The volume of PCR mixture is $20 \mu \mathrm{L}$, consisting of $12 \mu \mathrm{l}$ master mix, $1 \mu \mathrm{l}$ forward $400 \mathrm{nM}$ primer, $1 \mu \mathrm{l}$ reverse $400 \mathrm{nM}$ primer, $1 \mu \mathrm{l} 125 \mathrm{nM}$ probe, and $5 \mu \mathrm{l}$ nuclease free water. About $5 \mu \mathrm{l}$ of extracted DNA was added to the PCR mixture, then placed into MicroAmp optical plates (Applied Biosystems). PCR was carried out with the following conditions: predenaturation for 10 minutes at $95^{\circ} \mathrm{C}, 40$ cycles consisting of denaturation for 10 seconds at $95^{\circ} \mathrm{C}$, annealing and extension for 60 seconds at $60^{\circ} \mathrm{C}$. Positive filariasis is defined as raised of fluorescence signal compared to negative control.

\section{RESULTS AND DISCUSSION \\ Microscopic examination}

Microscopic examination in all sampling times shows positive microfilaria varied from 0 until six microfilariae, with the highest number of microfilaria detected on the sample collected at $4 \mathrm{pm}$ (Table 2). 
Table 2. Number of microfilaria found on blood smears

\begin{tabular}{ccc}
\hline No. & Time & Microfilariae \\
\hline 1. & 18.00 & 2 \\
2. & 20.00 & 1 \\
3. & 22.00 & - \\
4. & 24.00 & - \\
5. & 02.00 & 2 \\
6. & 04.00 & 3 \\
7. & 06.00 & 2 \\
8. & 08.00 & 4 \\
9. & 10.00 & 1 \\
10. & 12.00 & - \\
11. & 14.00 & 1 \\
12. & 16.00 & 6 \\
13. & 18.00 & 3 \\
\hline
\end{tabular}

Detected microfilaria has morphology with a length of $200 \mu \mathrm{m}$ and a width of $\pm 5 \mu \mathrm{m}$, respectively (Figure 1). Microfilariae are covered by a sheath with a blunt anterior tip with two styles, while the posterior tip pointed. Comparison of the length and width of the cephalic space is 2: 1 . Inner microfilariae look rough, arranged irregularly to posterior with two terminal nuclei. The microscopic appearance shows that the microfilariae are $B$. malayi.

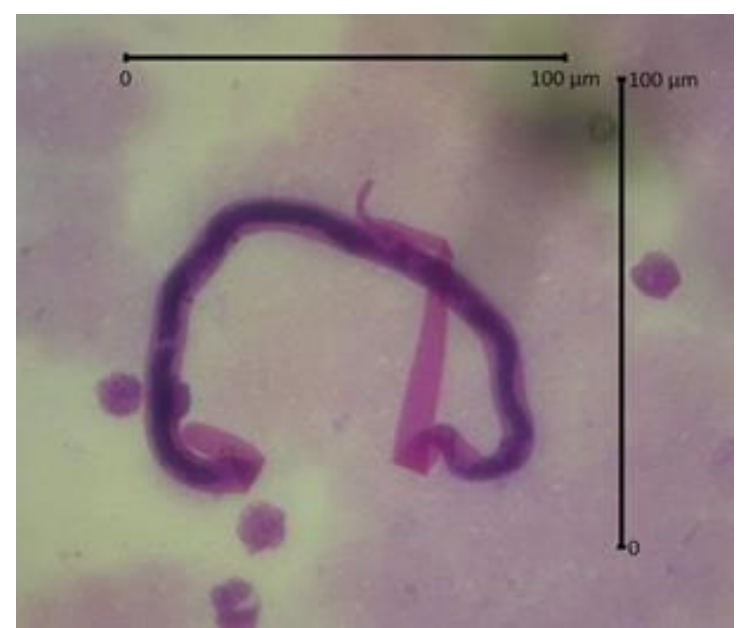

Figure 1. Microscopic appearance of B. malayi (100x)

\section{Real-time PCR}

The blood smear used for real-time PCR are slides containing three microfilariae. One slide scraped by wet method is labeled with "W," and other rubbed with the dry process is marked with "D." While samples from venous blood tagged with "V." 


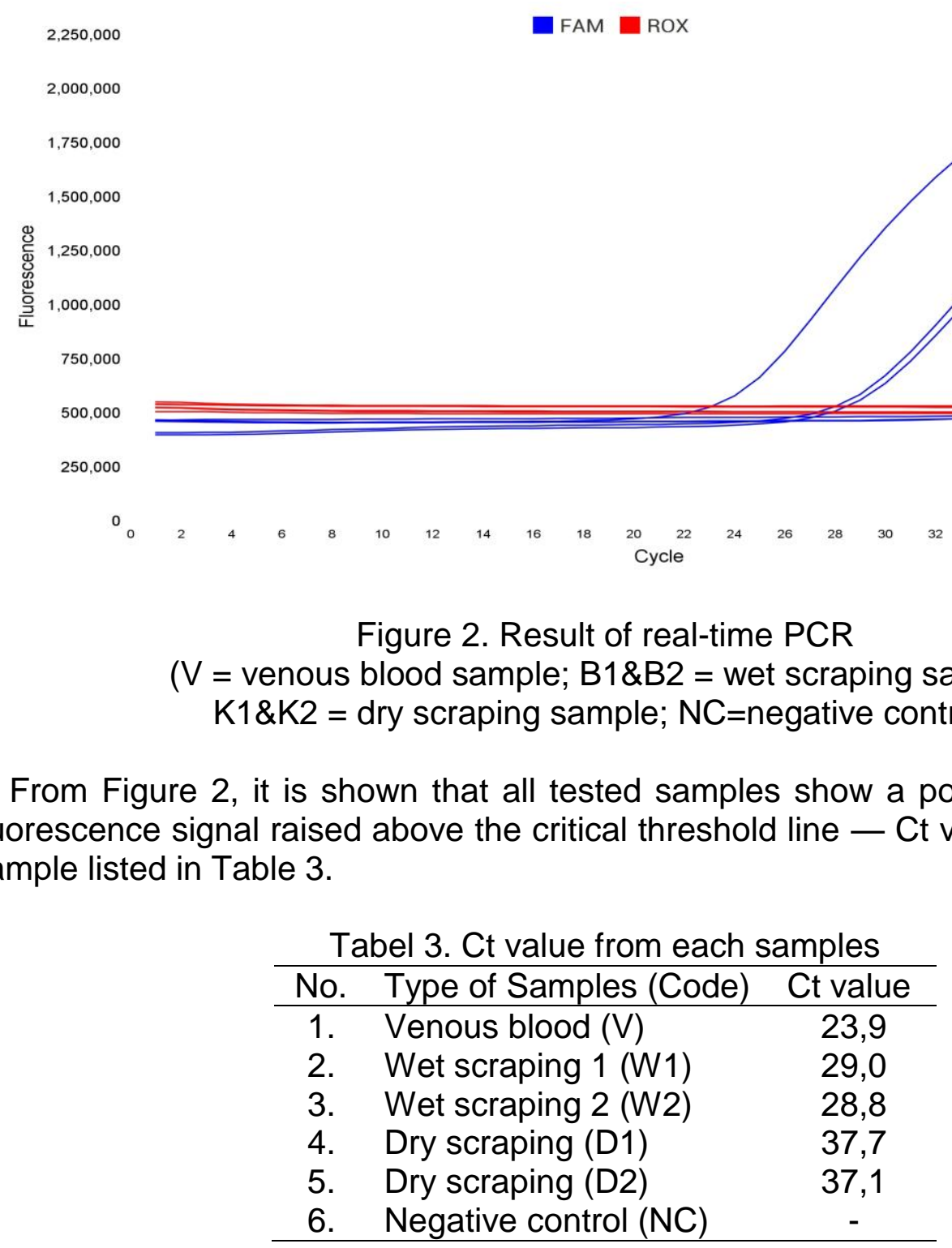

Filariasis is a worm infection which it's the gold standard in diagnosis is using Giemsa blood smear to find microfilaria. This method is easy to perform, fast, and doesn't need a sophisticated apparatus. Similar to another microscopic test, this method highly depends on individual skill to find microfilaria structure in blood smear, which lacked its specificity. Moreover, finding microfilaria in the blood sample can give false negative diagnosis when the number of circulated of microfilaria is limited. Polymerase chain reaction (PCR) is a molecular-based method to detect the specific pathogen in patient samples. In this study, we use 2.5 years stored slide of Giemsa blood smear which total DNA was isolated using a commercial kit. The effects of the Giemsa on DNA was shown for not significant, even though there is intercalation of these compounds with DNA strands (Meisner et al., 1974 and Kassaza et al., 2017).

Several other studies that used Giemsa blood smear as a DNA source also showed good results. Examination of $W$. bancrofti on Giemsa blood smear showed a strong correlation between real-time PCR results and microscopic results (Ferlianti et al., 2012). Similar results found in other genus parasites such as Plasmodium. The five-year-old plasmodium blood smear examined by PCR gave good results, even in low parasitemia (Kumar et al., 2016). The blood smear from P. falciparum which has 
stored for two years gives a positive result on PCR, even though the number of the parasites are deficient, around ten parasites/ $\mu$ l (Kumar et al., 2016). A blood smear of Leishmania, a parasite that attacks the skin, which has stored for 12 years also gives positive results on PCR examination. The storage time of Leishmania blood smear does not affect the level of detection of PCR (Barroso et al., 2018).

In this study, PCR showed positive results in both wet scraping and dry scraping samples. However, Ct from wet scraping sample is smaller than dry scraping sample (Table 2), indicating more amount of DNA detected in wet scraping sample. There are several reasons that may be the cause for this different amount of DNA. In dry scraping method, the microfilariae may not completely taken through physical approach or possibility of DNA damage may occur due to this physical pressure (scraping).

The study also found a significant difference between Ct of venous blood and Ct of blood smear (Table 3). The Ct value of venous blood is smaller, which means higher levels of microfilariae DNA in venous blood samples. This result occurs because the venous blood sample used in the extraction process has more volume $(200 \mu \mathrm{l})$ compared to the blood smear sample $(60 \mu \mathrm{l})$. The amount of blood in the venous blood sample is more flexible than the blood smear sample so that researchers can adjust the volume of venous blood for examination. This volume setting cannot do on blood smear samples.

Because of its limitations, the use of samples from microscopic slides is unusual for routine examinations. If venous blood collection cannot be done, for example, research in remote areas or there are only a few staff who can take venous blood, then the filter paper method can be used. The process of taking blood for filter paper is much easier. The process of sending and transporting filter paper is also easier. Both conventional and real-time PCR are able to detect DNA from blood samples on filter paper (Rahmah et al., 2010 and Nonsaithong et al., 2018). Another alternative for blood collection is using a microtainer. However, this method is more expensive than filter paper. Same with filter paper, microtainer also uses samples from finger blood.

The use of blood smear samples is useful for certain cases. For example, cases where the results of microscopic examinations are doubtful and no other type of sample can be used to confirm. Blood smear samples are also often used for retrospective studies. In some retrospective studies, the only sample that could be obtained was a microscopic sample, which was initially not intended for PCR examination.

\section{CONCLUSION}

This study shows that stored giemsa blood smears can be used as samples to detect nor confirmed microfilariasis using real-time PCR method. For better result, wet scraping method is recommended for extracting the DNA.

\section{ACKNOWLEDGMENT}

We thank Fithriyah Sjatha PhD, from Microbiology Department, Faculty of Medicine, Universitas Indonesia for proof-reading the manuscript before submission. We also would like to thank the Central Kalimantan Provincial Health Office, the Kapuas District Health Office, and the Dadahup Health Center for their assistance in collecting samples. 


\section{REFERENCE}

Albers, A., Sartono, E., Wahyuni, S., Yazdanbakhsh, M., Maizels, R. M., KlarmannSchulz, U., ... Hoerauf, A. (2014). Real-time PCR detection of the Hhal tandem DNA repeat in pre- and post-patent Brugia malayi Infections: a study in indonesian transmigrants. Parasites \& Vectors, 7(1), 146. https://doi.org/10.1186/1756-3305-7-146

Barroso, P. A., Krolewiecki, A. J., Nasser, J. R., Gil, J. F., Fleitas, P. E., Hoyos, C. L., ... Copa, G. N. (2018). Molecular Identification of Leishmania spp. DNA from Archived Giemsa-Stained Slides of Patients from Salta, Argentina. The American Journal of Tropical Medicine and Hygiene, 99(5), 1156-1161. https://doi.org/10.4269/ajtmh.18-0223

Ferlianti, R., Supali, T., \& Wibowo, H. (2012). Optimization of Real Time PCR for the Diagnosis of Bancrofti Filariasis in Thick Blood Smears. Jurnal Kedokteran Yarsi, 20(1), 14-22.

Gleave, K., Cook, D., Taylor, M. J., \& Reimer, L. J. (2016). Filarial infection influences mosquito behaviour and fecundity. Scientific Reports, 6(October), 18. https://doi.org/10.1038/srep36319

Kapuas District Health Office. (2015). Health Profile of Kapuas District 2015. Kapuas: Kapuas District Health Office Central Borneo.

Kassaza, K., Operario, D. J., Nyehangane, D., Coffey, K. C., Namugosa, M., Turkheimer, L., ... Boum, Y. (2017). Detection of Plasmodium Species by HighResolution Melt Analysis of DNA from Blood Smears Acquired in Southwestern Uganda. Journal of Clinical Microbiology, 56(1). https://doi.org/10.1128/JCM.01060-17

Khademvatan, S., Neisi, N., Maraghi, S., \& Saki, J. (2011). Diagnosis and identification of Leishmania spp. from Giemsa-stained slides, by real-time PCR and melting curve analysis in south-west of Iran. Annals of Tropical Medicine and Parasitology, 105(8), 559-565.

Kumar, D., Dhiman, S., Rabha, B., Goswami, D., Yadav, K., Deka, M., ... Baruah, I. (2016). Typing of Plasmodium falciparum DNA from 2 years old Giemsa-stained dried blood spots using nested polymerase chain reaction assay. Indian Journal of Medical Microbiology, 34(2), 210. https://doi.org/10.4103/0255-0857.176841

Meisner, L. F. (1974). Dye-nucleoprotein interactions in Giemsa banding. The Journal of Cell Biology, 61(1), 248-253. https://doi.org/10.1083/jcb.61.1.248

Ministry of Health. (2018). Health Profile of Indonesia 2017. Jakarta: Indonesia Ministry of Health.

Nonsaithong, D., Yotmek, S., Yotmek, S., Nochote, H., Wongkamchai, S., Roytrakul, S., \& Lek-Uthai, U. (2018). High resolution melting real-time PCR detect and identify filarial parasites in domestic cats. Asian Pacific Journal of Tropical Medicine, 11(12), 682. https://doi.org/10.4103/1995-7645.248340

Rahmah, N., Nurulhasanah, O., Norhayati, S., Zulkarnain, I., \& Norizan, M. (2010). Comparison of conventional versus real-time PCR detection of Brugia malayi DNA from dried blood spots from school children in a low endemic area. Tropical Biomedicine, 27(1), 54-59.

Rao, R. U., Weil, G. J., Fischer, K., Supali, T., \& Fischer, P. (2006). Detection of Brugia parasite DNA in human blood by real-time PCR. Journal of Clinical Microbiology, 44(11), 3887-3893. https://doi.org/10.1128/JCM.00969-06

Smit, P. W., Elliott, I., Peeling, R. W., Mabey, D., \& Newton, P. N. (2014). Review 
article: An overview of the clinical use of filter paper in the diagnosis of tropical diseases. American Journal of Tropical Medicine and Hygiene, 90(2), 195-210. https://doi.org/10.4269/ajtmh.13-0463

WHO. (2015). 489 Global programme to eliminate lymphatic filariasis: progress report, 2014. Releve Epidemiologique Hebdomadaire, 90(38), 489-504. Retrieved from http://www.ncbi.nlm.nih.gov/pubmed/26387149

Wihokhoen, B., Dondorp, A. M., Turner, P., Woodrow, C. J., \& Imwong, M. (2016). Use of Blood Smears and Dried Blood Spots for Polymerase Chain ReactionBased Detection and Quantification of Bacterial Infection and Plasmodium falciparum in Severely III Febrile African Children. The American Journal of Tropical Medicine and Hygiene, 94(2), 322-326. https://doi.org/10.4269/ajtmh.15-0532

Wongkamchai, S., Mayoon, B., Wanachiwanawin, D., Foongladda, S., Nochote, H., Loymak, S., ... Province, N. (2014). Real-time PCR with high-resolution melting analysis for diagnosis of lymphatic filariasis. JITMM proceedings, 3, 23-30. 